\title{
Prediction of Land Erosion by USLE Method in Dibawah Lake Catchment Areas, Solok Regency
}

\author{
Raden Herdian Bayu Ash Siddiq
}

Department of Civil Engineering, Widyatama University, Indonesia

Copyright $\mathrm{C} 2019$ by authors, all rights reserved. Authors agree that this article remains permanently open access under the terms of the Creative Commons Attribution License 4.0 International License

\begin{abstract}
The Government of West Sumatra functioned Dibawah Lake as a tourist area. Besides that, it is also used as an irrigation water source. Location of the Dibawah Lake, which is in the highlands with slope levels between $28 \%$ - $40 \%$ gives rise to the potential for land erosion in the lake catchment area, which is quite high. This study aims to predict the magnitude of land erosion, sediment delivery ratio and sedimentation rate in lake bodies using topographic spatial analysis and the USLE (Universal Soil Loss Equation) method. From the results of the analysis, it was found that the Dibawah Lake Catchment Area reached 2881.7 ha, which was divided into 27 sub-catchments. The rainfall erosivity value $(\mathrm{R})$ of the Dibawah Lake catchment area is $8219.46 \mathrm{~mm}$. The types of soils in the Dibawah Lake catchment area are cambisols and Andosols with soil erodibility values (K) 0.22 and 0.20 . The slope average of the Dibawah lake catchment area is $28 \%-40 \%$. The total land erosion in the Dibawah Lake catchment area is 1061.36 tons/ year. The Sediment Delivery Ratio (SDR) of the Dibawah Lake catchment area is 31.08\%. With an SDR value of $31.08 \%$, the sedimentation rate in the Dibawah Lake body is 329.85 tons/ year.
\end{abstract}

Keywords Dibawah Lake, Land Erosion, USLE, Sediment Delivery Ratio (SDR)

\section{Introduction}

Erosion is the event of moving or transporting land or parts of land from one place to another by natural media. In the event of erosion, the soil or parts of the land are eroded and transported, which are then deposited elsewhere. Erosion often occurs in wet climates, while wind erosion is an event that occurs in arid climates, while Indonesia is a tropical region that generally has a wet or rather wet climate (Arsyad 2010).

Dibawah Lake (Lake in Influence), Diatas Lake (Diateh Lake) and Talang Lake are located in Solok Regency,
West Sumatra, on the back of the Barisan Hill, which extends along the Sumatra Island. Diatas Lake and Dibawah Lake or often called Kembar Lake is a tectonic lake, which is at an altitude of 1531 masl (Lake Above) and 1462 masl (Lake Below) (Pasi Lehmusluoto, 1997)

Dibawah Lake Catchment Area is in a fairly steep area with an average slope of $28 \%-40 \%$ or included in class III. Due to the fairly steep slope conditions, the potential for erosion is quite large, so it is feared that it will increase the level of sedimentation in the lake body. The rate of change in lake floor per year Lake Dibawah reaches $15 \mathrm{~cm} /$ year (Harman Ajiwibowo, 2018). To predict the rate of erosion in the Lake Dibawah catchment area, the USLE (Universal Soil Loss Equation) method is used. This equation was developed by Wischmeier and Smith (1978) used to calculate soil loss (Soil Loss), which is correlated with various parameters related to natural conditions and human activities. Natural conditions that cause erosion are generally expressed as potential erosion related to soil erodibility, rain erosivity and topographic characteristics of the land.

\section{Literature Review}

The research location is Dibawah Lake located in Solok Regency, West Sumatra Province. The Dibawah Lake is in a geographic position of approximately $1^{\circ} 0$ ' $35^{\prime \prime}$ Latitude of Debt and $100^{\circ} 43^{\prime} 51$ East Longitude. The outflow from this lake is the Lembang River, which empties into Lake Singkarak. The Dibawah Lake catchment area is a steep terrain and has been used for various purposes such as agriculture, agriculture and settlements.

Factors that influence erosion includes: climate, topography, vegetation, soil and human activities (Directorate of Agricultural Area Expansion Jakarta, 1986). In wet climate, the climate factor that affects is rain. The amount of rainfall, intensity, and rainfall distribution determine the soil dispersion strength, the amount and speed of surface flow, and erosion damage Slope and slope 
length are the two topographic elements that have the most influence on surface flow and erosion. Another element that might influence is configuration, uniformity and slope direction (Luong, Long, Tuan \& Thai, 2017; Obinna-Echem \& Torporo, 2018).

The influence of vegetation on surface runoff and erosion can be grouped into 5 parts: a) Rain interception by canopy plants; b) Reducing the speed of flow and strength of water destroyers; c) Effect of roots and biological activities related to vegetative growth; d) Its influence on structural stability and soil porosity; and e) Transpiration resulting in reduced soil water content.

Different types of soil have different sensitivities to erosion. Sensitivity of soil erosion is the ease or failure of soil, which is a function of various interactions of physical and chemical properties of the soil. In the end, it is human beings, who determine whether the land they cultivate will be damaged and unproductive or become good and sustainably productive.

The USLE method in Asdak $(2007 ; 356)$ is a method for predicting the level of soil erosion described in the equation:

$$
\begin{aligned}
& \mathrm{A}=\mathrm{R} \text { K L S C P } \\
& \text { Where: } \\
& \mathrm{A}=\text { Number of soil erosion (tons } / \text { ha / year) } \\
& \mathrm{R}=\text { Rain Erosion }(\mathrm{cm}) \\
& \mathrm{K}=\text { soil accessibility } \\
& \mathrm{L}=\text { lerang length }(\mathrm{m}) \\
& \mathrm{S}=\text { Slope of slope }(\%) \\
& \mathrm{C}=\text { Ground cover vegetation and crop management } \\
& \mathrm{P}=\text { Specific action factor for soil conservation used }
\end{aligned}
$$
(Arsyad, 2010; Vu \& Zhong 2018)

Erosion analysis using the USLE (Universal Soil Losses Equation) method produces an estimate of the amount of gross erosion. To determine the amount of sediment reaching the lake location, gross erosion will be multiplied by the sediment release ratio (Sediment Delivery Ratio). Sediment Delivery Ratio (SDR) is the ratio between the calculated export of sediment and erosion. According to Vanuni (1975), SDR can be calculated by the formula: $\mathrm{SDR}=0.42 \mathrm{~A}^{-0.125}$

Where $\mathrm{A}=$ Area of watershed in square miles

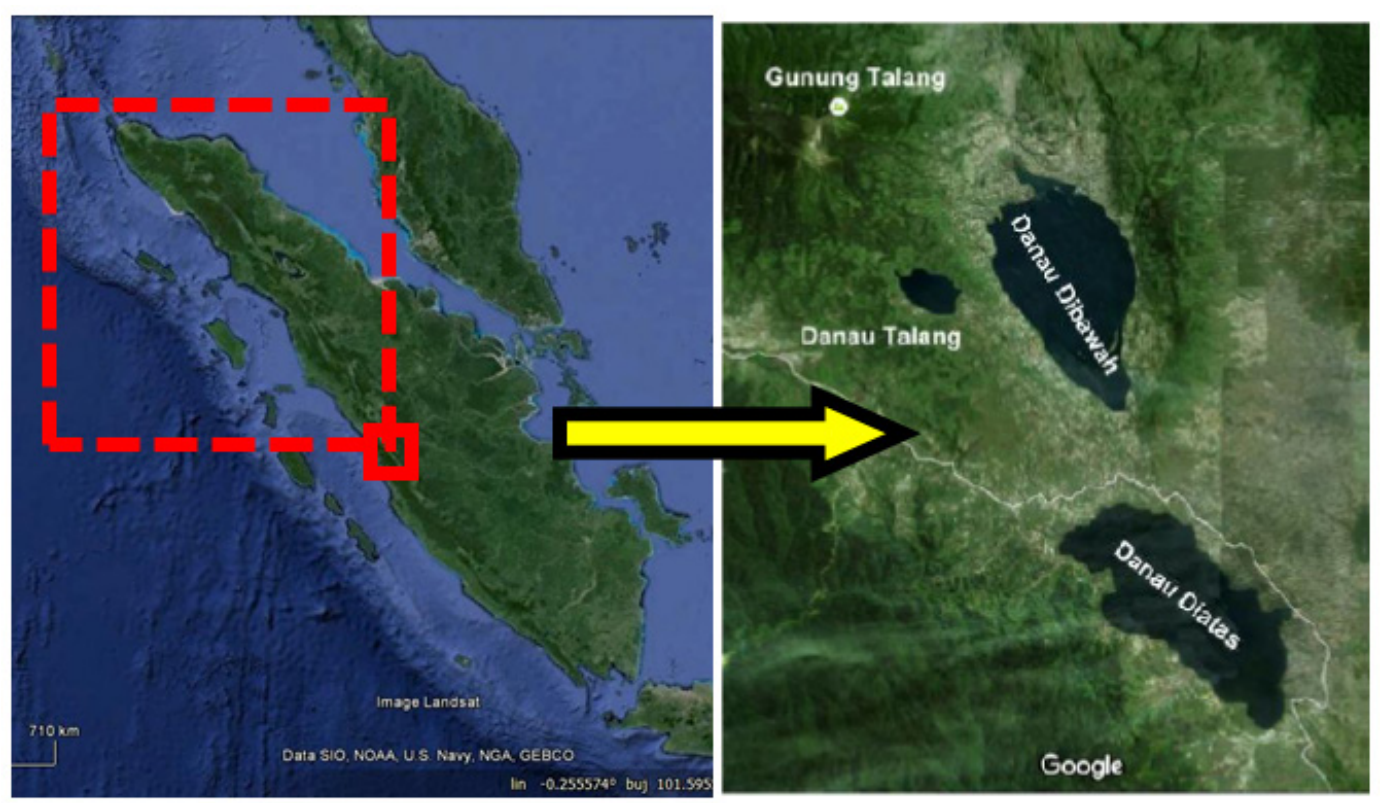

Figure 1. The Location of Dibawah Lake 


\section{Method}

This study was carried out through the collection, processing and analysis of secondary data from literature studies at universities, research institutions, relevant government institutions, to obtain references and data. In this study, ArcGIS 10.2 software was also used for spatial analysis and the creation of hazardous land erosion maps. Following is the flow of the calculation of predicted land erosion using the USLE method.

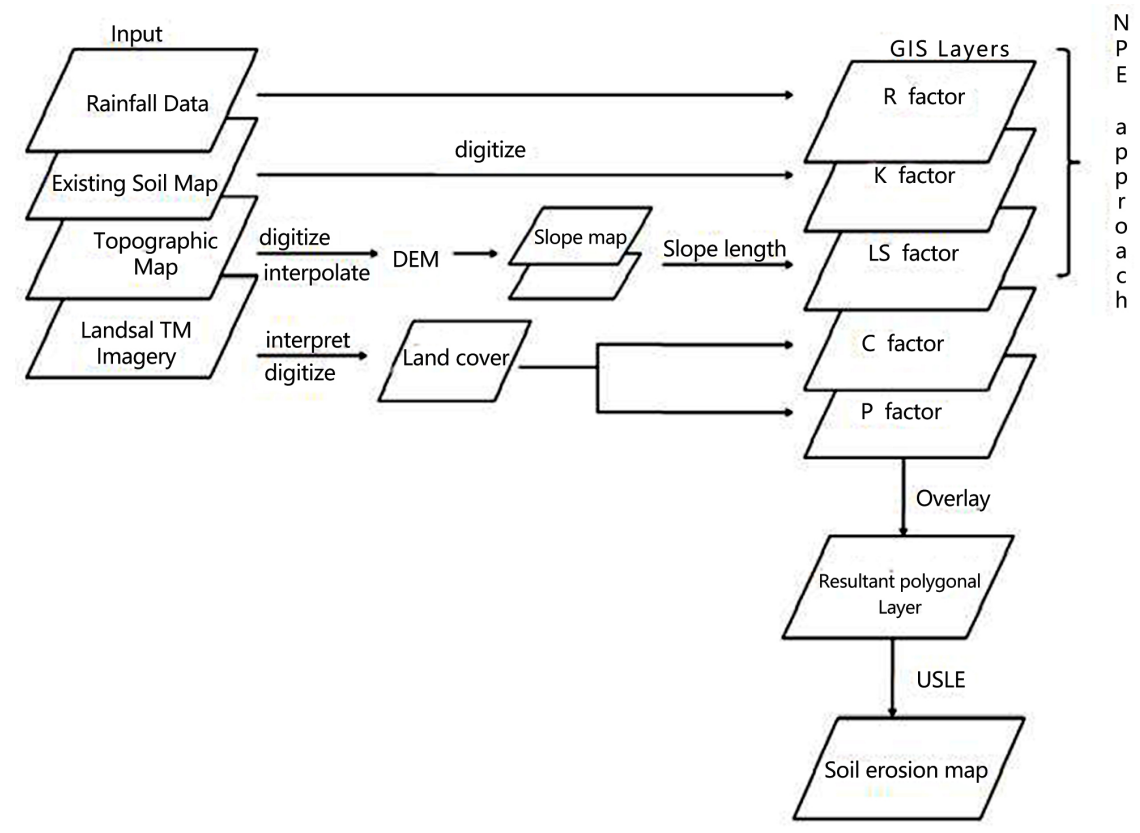

Figure 2. USLE Method Flowchart

\section{Result and Analysis}

\subsection{Catchment Area}

Based on the results of the topographic map analysis, it was found that the area of the Dibawah Lake catchment area reached 2881.7 ha divided into 27 sub-catchments.

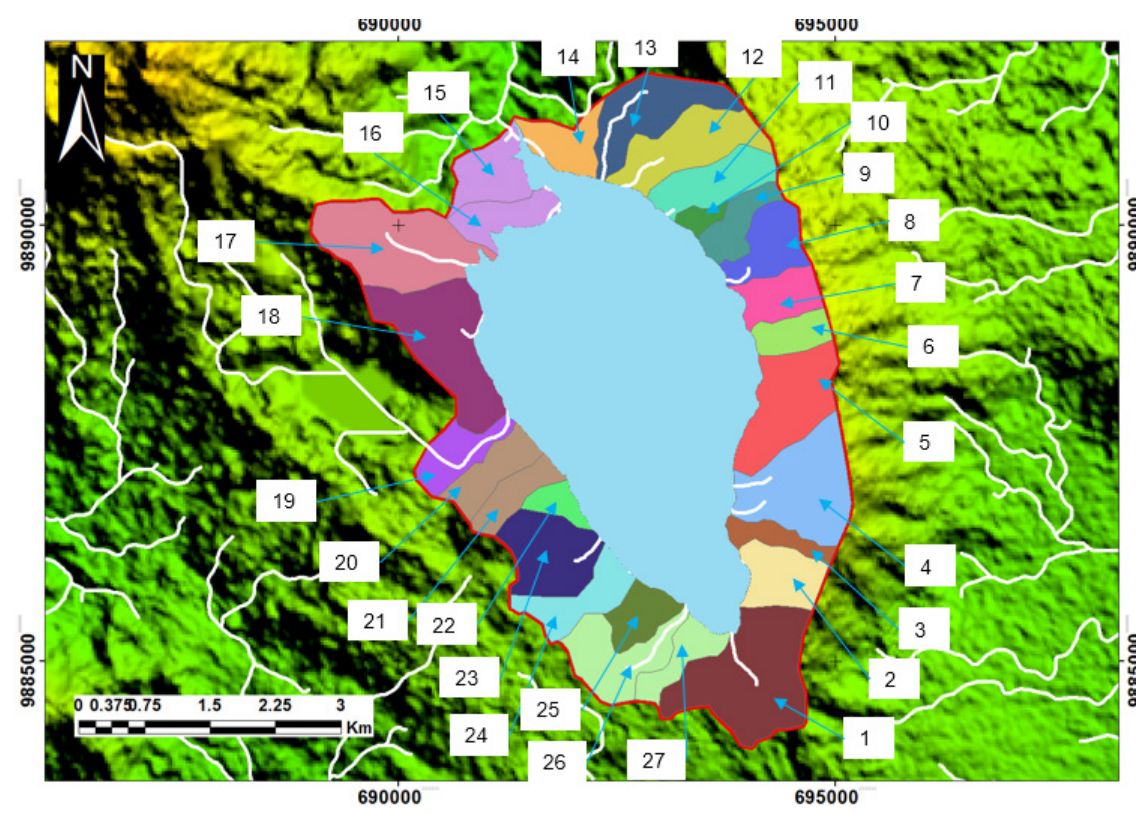

Figure 3. Dibawah Lake Subcatchment Area 


\subsection{Faktor Erosivitas Hujan (R)}

Factors of Rainy Erosion (R) The rainfall erosivity factor index value in this study was calculated using the Lenvain formula, namely:

$\mathrm{EI}=2.34$ (Rain) $\mathrm{m} 1.98$

Where:

$\mathrm{Rm}=$ Monthly rainfall erosion,

(Rain) $\mathrm{m}=$ Monthly rainfall in $\mathrm{dm}$

$R=\sum_{m=1}^{12}(R m)=$ Amount of $\mathrm{Rm}$ for 12 months.

Based on the calculation of rainfall data, it is known that the value of the precipitation erosivity index in the Dibawah Lake catchment area is $8219.46 \mathrm{~mm}$.

\subsection{Soil Erodibility Index (K)}

The soil erodibility factor shows that soil particles are resistant to peeling and transporting soil particles by the presence of rain water kinetic energy. The amount of soil erodibility or resistance is also formed by soil characteristics such as; soil texture, soil aggregate stability, infiltration capacity and organic matter content.

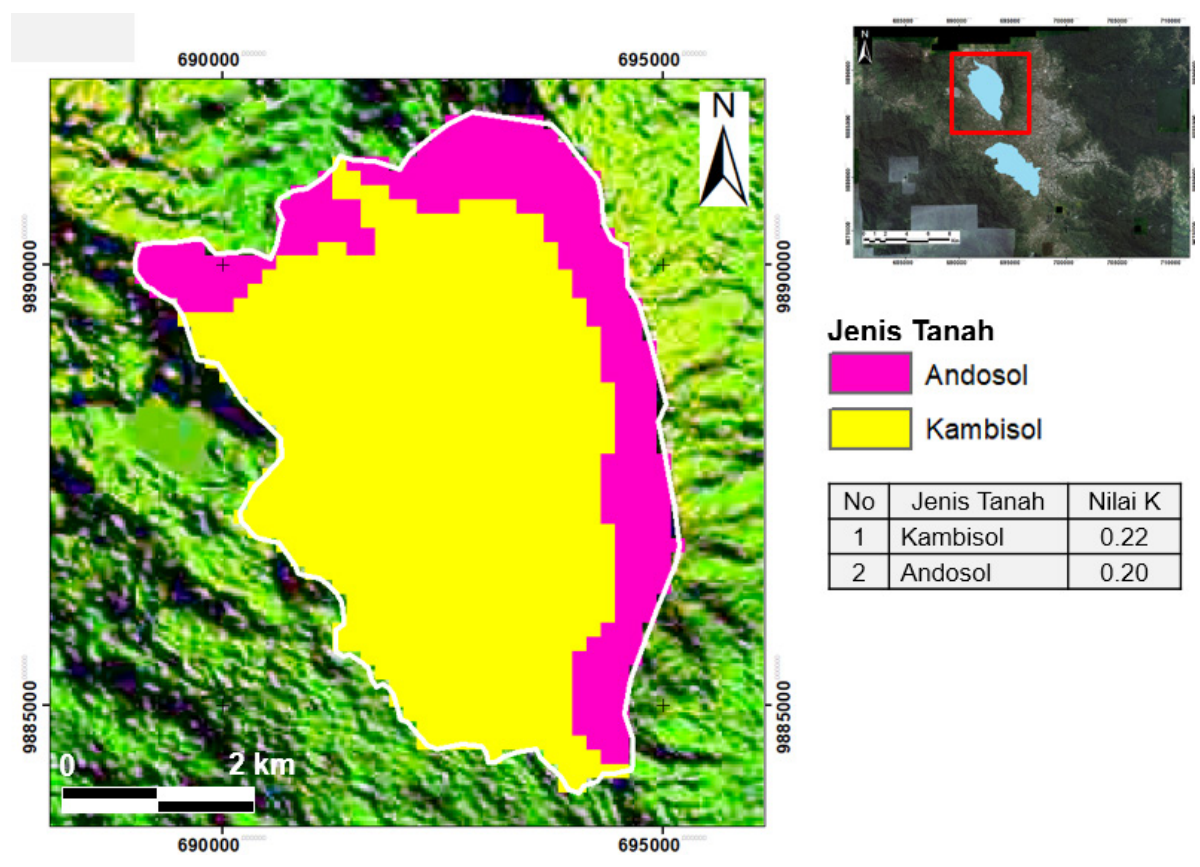

Figure 4. Dibawah Lake Erodibility Map based on type of soil

Slope Length and Slope Factors (LS)

Table 1. Dibawah Lake LS Value

\begin{tabular}{|c|c|c|c|}
\hline No & Slope Class & Slope (\%) & Nilai LS \\
\hline 1 & I & $0-15$ & 1 \\
\hline 2 & II & $15-28$ & 4 \\
\hline 3 & III & $28-40$ & 7 \\
\hline 4 & IV & $40-55$ & 13 \\
\hline 5 & V & $55-148$ & 88 \\
\hline
\end{tabular}




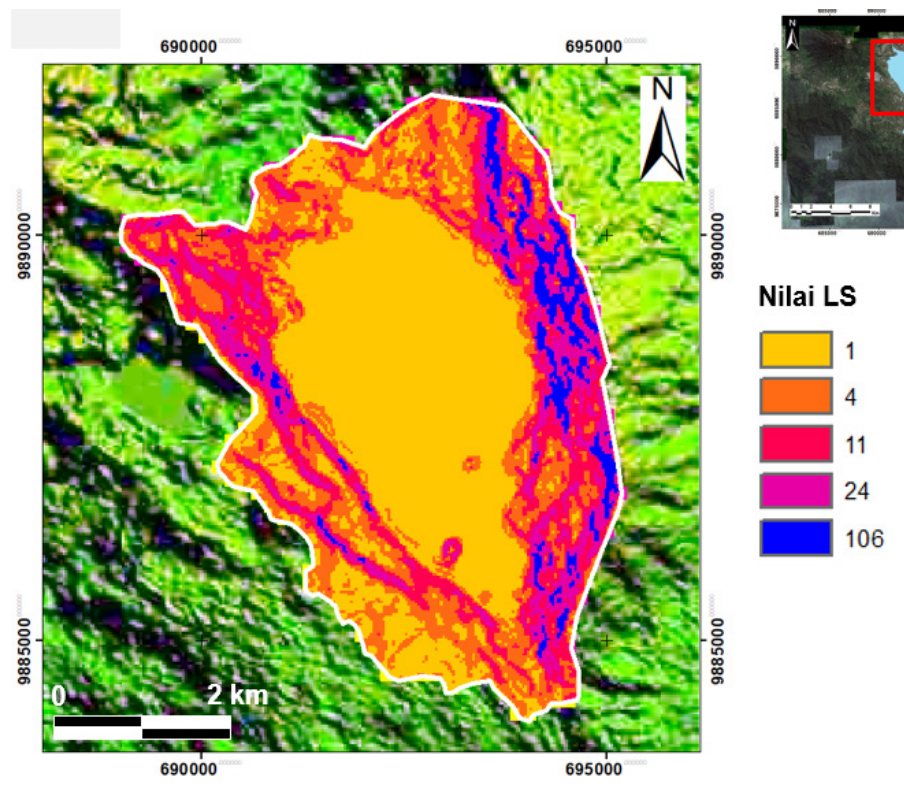

Figure 5. Spatial Map of LS Value in Dibawah Lake

Cover Crop Management Factors and Land Management (CP)

\section{Factor}

The better the protection of soil surface by food crops / vegetation is, the lower the level of erosion will be. Factor C values ranged from 0.001 in undisturbed forest to 1.0 in vacant land. The average annual $\mathrm{C}$ calculation for each land unit is determined based on the crop period using a balanced average index.

\section{P Factor $(\mathrm{P})$}

The factor of land management is the ratio between the amount of erosion or soil lost to the land with certain preservation measures to the extent of soil erosion.

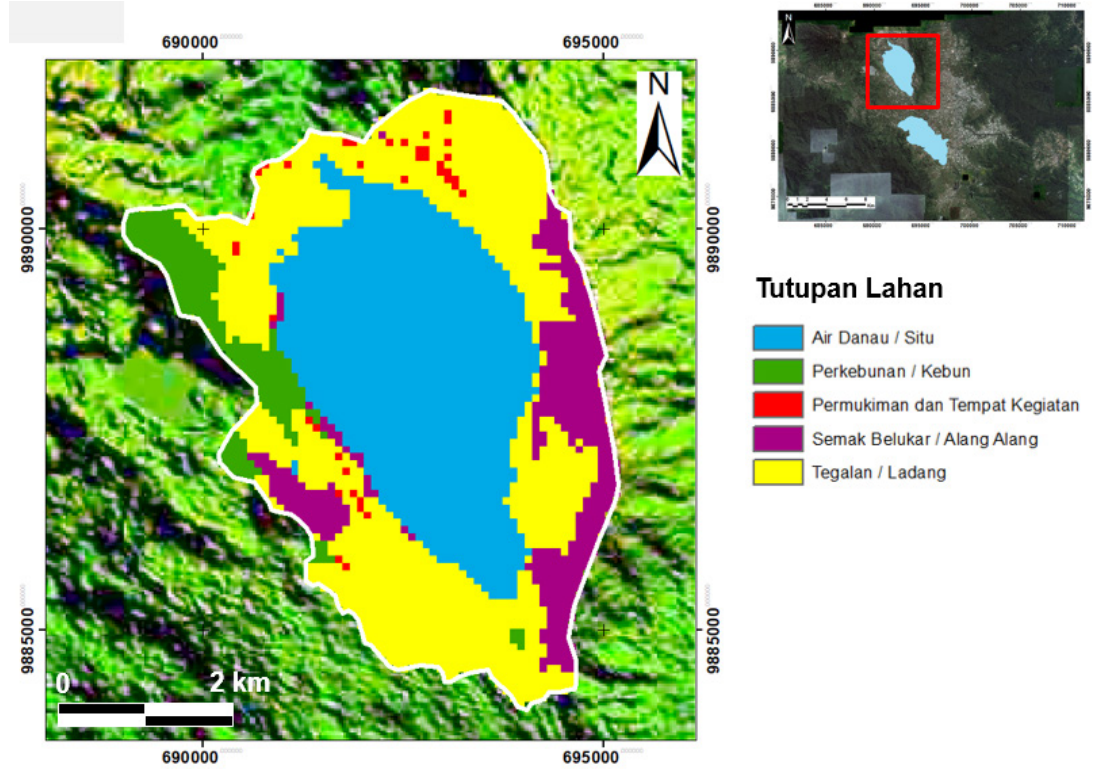

Figure 6. Spatial Map of CP Value in Dibawah Lake

\subsection{Erosi Lahan}

The results of the actual erosion calculation in Lake Catchment Area Under the USLE method were obtained 1061.36 tons/ year. Actual erosion distribution map of catchment waters (bottom catchment) of the bottom lake can be seen in the picture below. 

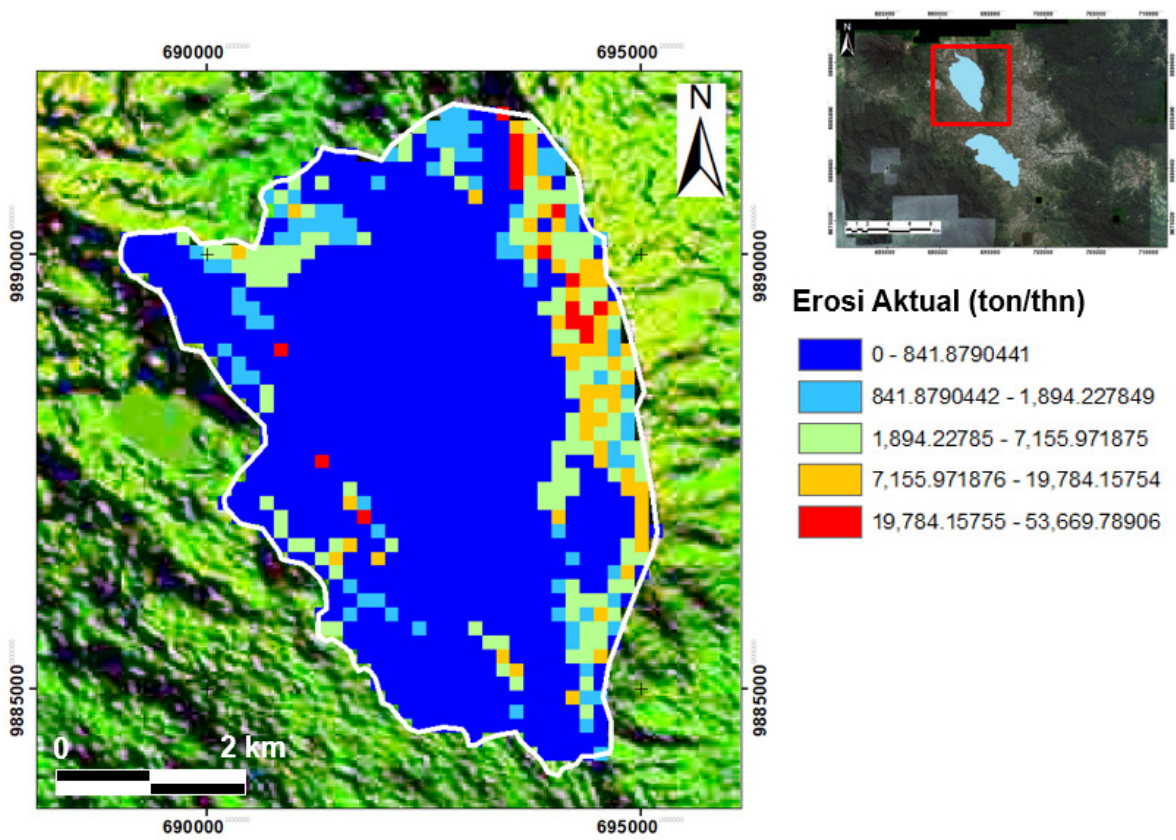

Erosi Aktual (ton/thn)

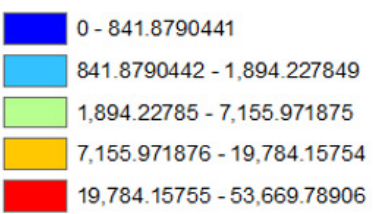

Figure 7. Value of Erosion Land in Dibawah Lake

\subsection{Sediment Delivery Ratio (SDR)}

From the calculation results obtained Sediment Delivery Ratio (SDR), Dibawah Lake with a catchment area of 2881.7 ha is $31.08 \%$. So that the prediction of sedimentation rate in the lake below, which comes from land erosion is 329.85 tons/ year.

\section{Conclusions}

1. The Dibawah Lake catchment area reaches 2881.7 ha, divided into 27 sub-catchments.

2. Rainfall erosion value (R) Dibawah Lake catchment area $8219.46 \mathrm{~mm}$.

3. The type of soil in the Dibawah Lake catchment area is cambisol and Andosol with soil erodibility values (K) 0.22 and 0.20 .

4. The slope average of the Dibawah Lake catchment area is $28 \%-40 \%$.

5. Total land erosion in the Dibawah Lake catchment area is 1061.36 tons / year.

6. The Sediment Delivery Ratio (SDR) of the Dibawah Lake catchment area is $31.08 \%$.

7. With an SDR value of $31.08 \%$, the sedimentation rate in the Dibawah Lake body is 329.85 tons/ year.

\section{REFERENCES}

[1] Weischmeir dan D/D Smith. 1978. Predicting Rainfall Erosian Losses guide to Conservation Planning. U. S. Department of Agriculture. Agriculture Hand Book no 537.
[2] Lehmusluto, P\&B. Mahbub 1997. National Inventory of the Major Lakes and Reservoirs in Indonesian. General Limnology. Expedition Indodanau Technical Report. Indonesia-Finland. Revised Edition.

[3] Arsyad S. 2010. Soil and Water Conservation. Second edition Second print. Bogor (ID): IPB Press Publisher. Asdak C. 2007. Hydrology and Management of Watersheds. UGM Press.

[4] Ajiwibowo H, RHB Ash Shiddiq \& MB Pratama, "Assessment of Hydro-Environmental Condition Using Numerical Modelling in Dibawah Lake, Western Sumatera, Indonesia", International Journal of Geomate, vol. 115, 2018, pp.140-146.

[5] Ridwansyah I, "Morphometry Study, Aquatic Zone and Stratification of Temperature of Lake Above West Sumatra," Limnotek, 2009, XVIN vol. 1, p.22-32.

[6] Indrawaty N, Mulyadi A, Zulkarnain, "Evaluation of Land Use in Lake Artificial Tassel Catchment Area at Pekanbaru City", Journal of Environmental Sciences, 2016: 10 (1)

[7] ILEC, 2005, Managing lake and Their Basins for Sustainable Use, A Report for Lake Basin Management and Stakeholders. International Lake Environment Committee Fondation: Kutsasu, japan.

[8] Trisuryono, 2007, Study and Development of Limnologic Characteristics of Inland Waters in Indonesia, Technical Report of DIPA 2007, Research Center for Limnologi-LIPI

[9] Vu, G. X. M., \& Zhong, Z. W. (2018). Forecasting Air Passengers of Changi Airport Based on Seasonal Decomposition and an LSSVM Model. Review of Information Engineering and Applications, 5(1), 12-30.

[10] Obinna-Echem, P. C., \& Torporo, C. N. (2018). Physico-Chemical and Sensory Quality of Tigernut (Cyperus Esculentus)-Coconut (Cocos Nucifera) Milk Drink. Agriculture and Food Sciences Research, 5(1), 
23-29.

[11] Luong, N. D., Long, H. V., Tuan, N. K., \& Thai, N. D.

(2017). Properties of Concrete Containing Rubber Aggregate Derived From Discarded Tires. Asian Review of

Environmental and Earth Sciences, 4(1), 12-19. 